Manson, E. E. D. \& Pollock, M. R. (1953). J. gen. Microbiol. 8, 163-167.

\title{
The Thermostability of Penicillinase
}

\author{
By EILEEN E. D. MANSON and M. R. POLLOCK \\ National Institute for Medical Research, Mill Hill, N.W.7
}

SUMMARY : Extracellular penicillinase produced by the growth of five different strains of the genus Bacillus in casein hydrolysate is rapidly inactivated at $100^{\circ}$, but can be strikingly protected against such inactivation by addition of $1 \%$ gelatin or high molecular weight substances present in tryptic digest and meat infusion broth.

Since Abraham \& Chain (1940) first described penicillinase there have been conflicting reports on the thermostability of the enzyme. Most workers (see Florey, Chain, Heatley, Jennings, Sanders, Abraham \& Florey, 1949) have reported rapid destruction on heating above $50^{\circ}$ in aqueous solution at neutral pH. Duthie (1944), however, showed that penicillinase in the filtrate of a broth culture of Bacillus subtilis was unaffected by heating at $100^{\circ}$ for $20 \mathrm{~min}$. at $\mathrm{pH} 7 \cdot 0$, and Smith \& Smith (1945) reported that penicillinase from a strain of paracolon bacillus was stable at $100^{\circ}$ for $30 \mathrm{~min}$. when dry, but was completely inactivated in aqueous solution. In view of these reports it was decided to test a number of penicillinase preparations from different bacterial cultures of the genus Bacillus to discover whether their thermostability was determined by the strain of organism used.

\section{METHODS}

Media and materials. Casein hydrolysate medium (CH) was made from acid hydrolysed vitamin-free casein (Allen and Hanbury's Ltd.) $0 \cdot 8 \%$ (w/v) supplemented with $8 \times 10^{-5} \mathrm{M}$-L-tryptophan, $2 \times 10^{-4} \mathrm{M}$-DL-cystine, $1.7 \times 10^{-3} \mathrm{M}_{-} \mathrm{MgSO}_{4}$ and $0 \cdot 02 \mathrm{M}$-phosphate buffer, $\mathrm{pH} 7 \cdot 0$.

Infusion broth was prepared as described by Wright (1933), but using only a quarter of the amount of water, to give a concentrated medium. Tryptic digest broth was prepared as described by Hartley (1922).

The penicillin used was sodium benzylpenicillin from Glaxo Laboratories Ltd. The gelatin solutions were prepared from 'Difco' standardized gelatin.

Five commercial penicillinase preparations $(\mathrm{A}-\mathrm{D}$ and $\mathbf{F})$ and the strains used in their production, with the exception of strain $\mathbf{F}$, were obtained. These commercial strains were called (A) B. licheniformis, (B) B. cereus, (C) B. subtilis and (D) B. subtilis and were used for the laboratory penicillinase preparations together with a penicillinase-producing strain of $B$. cereus (NRRL 569 designated here as $\mathbf{E}$ ).

Enzyme production. Washed cell suspensions were prepared from CCY medium (Gladstone \& Fildes, 1940) (organisms A-D) or tryptic digest broth (organism $\mathrm{E}$ ) after incubation for $18-24 \mathrm{hr}$. at $35^{\circ}$ on a bacteriological shaker. The dry weights were determined by opacity measurements on the 'Spekker' absorptiometer by reference to a standard curve of the relation between 
opacity and dry weight. Cell suspensions at an initial concentration of $1 \mathrm{mg} . / \mathrm{ml}$. were incubated in $50 \mathrm{ml}$. $\mathbf{C H}$ medium or tryptic digest broth in a $250 \mathrm{ml}$. conical flask and penicillin (1-10 units $/ \mathrm{ml}$.) was added to increase the yield of enzyme. These cultures were shaken for $3-3 \frac{1}{2} \mathrm{hr}$. at $35^{\circ}$ before the cells were centrifuged off. The supernatant fluids (having penicillinase activities from 200 to $1000 \mu \mathrm{l} . \mathrm{CO}_{2} / \mathrm{hr}$. $/ \mathrm{ml}$.) were stored at $2^{\circ}$.

Gelatinase activity. Strains were tested for gelatinase activity by incubating 'stab' cultures in broth containing $15 \%(\mathrm{w} / \mathrm{v})$ gelatin for 3 weeks at $18^{\circ}$; a positive result was recorded if any liquefaction had occurred. The culture supernatant fluids were similarly tested, after sterilization by filtration, by incubating $0.5 \mathrm{ml}$. on the surface of $2 \mathrm{ml}$. of the gelatin-broth in a test-tube at $18^{\circ}$ for 5 days.

Penicillinase assay. The enzyme was assayed manometrically at $\mathrm{pH} \mathbf{7 \cdot 0}$ and $30^{\circ}$ by the method of Henry \& Housewright (1947), and the penicillinase activity expressed in $\mu \mathrm{l} . \mathrm{CO}_{2}$ liberated $/ \mathrm{hr}$. $/ \mathrm{ml}$. of medium. No corrections have been made for the small amounts of $\mathrm{CO}_{2}$ retention in the different media, which will cause a slight error in the enzyme activity values. The flask constants did not vary enough for such retention to affect comparative results.

Heat stability test. A $250 \mathrm{ml}$. flask with a stoppered side arm was connected to a water cooled reflux condenser and placed in a boiling water-bath. Through the side arm, so made that a pipette passing through it could reach the base of the flask, approximately $8 \mathrm{ml}$. of enzyme solution were added rapidly. Samples of $2 \mathrm{ml}$. were removed at intervals and immediately placed in testtubes, precooled in a beaker of ice, and kept cold until assayed.

\section{RESULTS}

The thermostability of the five commercial preparations was examined; three $(A-C)$ were found to be fairly stable at $100^{\circ}$, whereas the other two (D, F) were rapidly inactivated (see Table 1 ).

Further studies were made of the thermostability of penicillinase from four of the organisms concerned (A-D) and also organism (E).

Gelatin. Enzyme produced in $\mathbf{C H}$ medium was found to be rapidly inactivated at $100^{\circ}$ irrespective of the bacterial strain used or stability of the commercial preparation; but this inactivation was markedly reduced if $1 \%$ $(w / v)$ gelatin was added to the enzyme preparation before heat treatment. Enzyme produced in a 'complex' medium, e.g. tryptic digest broth, was inactivated only slightly at $100^{\circ}$ and to about the same extent as $\mathrm{CH}$ preparations containing $1 \%$ gelatin (Table 1 and Fig. 1). The concentration of gelatin which gave maximum protection was found to be $1 \%$ when a range of concentrations from $\mathbf{0 . 0 1}$ to $2.5 \%(\mathrm{w} / \mathrm{v})$ was tested (Table 2). A twofold difference in concentration of enzyme (from growth of $\mathbf{E}$ in $\mathbf{C H}$ ) did not affect the extent of protection afforded by $1 \%$ gelatin.

The addition of 1 and $2.5 \%$ gelatin to the commercial preparation $(F)$ had no protective effect on the enzyme which was still completely inactivated after 2 min. at $100^{\circ}$. 
Table 1. Thermostability of penicillinase preparations

\begin{tabular}{|c|c|c|c|c|c|c|c|}
\hline \multirow[b]{2}{*}{ Organism } & \multicolumn{3}{|c|}{ Cornmercial preparation } & \multicolumn{3}{|c|}{ Laboratory preparation } & \multirow[b]{2}{*}{$\begin{array}{c}\text { Time of } \\
\text { heating } \\
\text { (min.) }\end{array}$} \\
\hline & $\begin{array}{l}\text { Growth } \\
\text { medium }\end{array}$ & $\begin{array}{l}\text { Activity } \\
\left(\mu \mathrm{l} . \mathrm{CO}_{2} /\right. \\
\text { hr. } / \mathrm{ml} .)\end{array}$ & $\begin{array}{l}\text { Residual } \\
\text { activity } \\
(\%)\end{array}$ & $\begin{array}{c}\text { Casein } \\
\text { hydro- } \\
\text { lysate } \\
\text { - gelatin } \\
(\%)\end{array}$ & $\begin{array}{l}\text { Casein } \\
\text { hydro- } \\
\text { lysate } \\
\text { + gelatin* } \\
(\%)\end{array}$ & $\begin{array}{l}\text { Hartley } \\
\text { broth } \\
\text { - gelatin } \\
(\%)\end{array}$ & \\
\hline $\begin{array}{l}\text { B. licheni- } \\
\text { formis }\end{array}$ & $\begin{array}{l}\text { Papain digest } 1: 3 \\
\text { distilled water } \\
+0.5 \% \text { glucose }\end{array}$ & 1080 & $\begin{array}{l}- \\
\overline{46} \\
20\end{array}$ & $\begin{array}{l}38 \\
38 \\
- \\
-\end{array}$ & $\begin{array}{l}92 \\
88 \\
- \\
-\end{array}$ & - & $\begin{array}{r}2 \\
5 \\
15 \\
60\end{array}$ \\
\hline B. cereus & $\begin{array}{l}\text { Difco yeast beef } \\
\text { broth }\end{array}$ & 4500 & $\begin{array}{l}- \\
80 \\
27\end{array}$ & $\begin{array}{l}19 \\
16 \\
-\end{array}$ & $\begin{array}{l}84 \\
80 \\
- \\
-\end{array}$ & $\begin{array}{l}87 \\
83 \\
87 \\
-\end{array}$ & $\begin{array}{r}2 \\
5 \\
15 \\
60\end{array}$ \\
\hline B. subtilis & $\begin{array}{l}\text { Tryptic digest } \\
\text { broth }+1 \% \\
\text { glucose }\end{array}$ & 600 & $\begin{array}{l}90 \\
85 \\
73 \\
37\end{array}$ & $\begin{array}{l}<0 \cdot 1 \\
<0 \cdot 1 \\
-- \\
-\end{array}$ & $\begin{array}{l}75 \\
70 \\
- \\
-\end{array}$ & 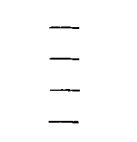 & $\begin{array}{r}2 \\
5 \\
15 \\
60\end{array}$ \\
\hline B. subtilis & Lemco broth & 700 & $\begin{aligned} & 4 \\
< & 0 \cdot 1 \\
< & 0 \cdot 1 \\
< & 0 \cdot 1\end{aligned}$ & $\begin{array}{l}22 \\
13 \\
- \\
-\end{array}$ & $\begin{array}{l}79 \\
73 \\
- \\
-\end{array}$ & $\begin{array}{l}84 \\
74 \\
65 \\
-\end{array}$ & $\begin{array}{r}2 \\
5 \\
15 \\
60\end{array}$ \\
\hline $\begin{array}{l}\text { B. cereus† } \\
\text { [RRL 569) }\end{array}$ & - & 一 & - & $\begin{array}{l}19 \\
14 \\
-\end{array}$ & $\begin{array}{l}48 \\
42 \\
-\end{array}$ & $\begin{array}{l}53 \\
47 \\
43\end{array}$ & $\begin{array}{r}2 \\
5 \\
15\end{array}$ \\
\hline Unknown $\dagger$ & Unknown & 340 & $\begin{array}{l}<0.1 \\
<0.1\end{array}$ & - & - & - & $\begin{array}{l}2 \\
5\end{array}$ \\
\hline
\end{tabular}

Residual activity figures represent percentage of original activity remaining after heating at $100^{\circ}$ for periods stated.

* $1 \%$ gelatin added to enzyme preparation.

$\dagger$ Positive gelatinase activity.

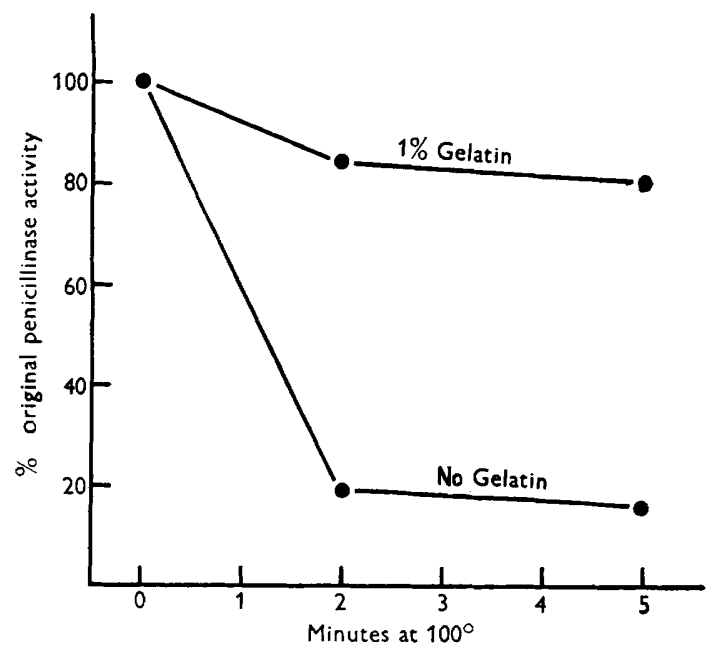

Fig. 1. Protective effect of $1 \%$ gelatin against inactivation of penicillinase at $100^{\circ}$. Enzyme was the supernatant fluid from a culture of organism $B$ in casein hydrolysate. 
Concentrated infusion broth. The addition of concentrated infusion broth to an equal volume of the enzyme preparation had the same protective effect as $1 \%$ gelatin. Concentrated broth $(25 \mathrm{ml}$.), when dialysed against glass-distilled water (4.5 l.) at $2^{\circ}$, suffered no loss in protective ability (Table 2 ).

\begin{tabular}{|c|c|c|c|}
\hline \multirow[b]{2}{*}{ Exp. } & \multirow[b]{2}{*}{ Added substance } & \multicolumn{2}{|c|}{$\begin{array}{l}\text { Percentage original activity } \\
\text { remaining after treatment } \\
\text { at } 100^{\circ} \text { for }\end{array}$} \\
\hline & & $2 \mathrm{~min}$. & $5 \mathrm{~min}$ \\
\hline \multirow[t]{3}{*}{ I } & Nil & 7 & 4 \\
\hline & Infusion broth & 71 & 69 \\
\hline & $\begin{array}{l}\text { Infusion broth after } \\
\text { dialysis for } 24 \mathrm{hr} \text {. }\end{array}$ & 71 & - \\
\hline \multirow[t]{6}{*}{ II } & Nil & 19 & 16 \\
\hline & $0.01 \%$ gelatin & 42 & 39 \\
\hline & $0.05 \%$ gelatin & 55 & 56 \\
\hline & $0.1 \%$ gelatin & 65 & 66 \\
\hline & $1.0 \%$ gelatin & 84 & 80 \\
\hline & $2.5 \%$ gelatin & 84 & 76 \\
\hline \multirow[t]{5}{*}{ III } & Nil & 11 & 17 \\
\hline & $5 \times 10^{-3} \mathrm{M}$ penicillin & 56 & 50 \\
\hline & $5 \times 10^{-2} \mathrm{M}$ penicillin & 76 & 76 \\
\hline & $5 \times 10^{-3} \mathrm{M}$ penicilloic acid & 28 & 25 \\
\hline & $5 \times 10^{-2}$ M penicilloic acid & 38 & 46 \\
\hline
\end{tabular}

Penicillin, added to the enzyme solution cooled to $0^{\circ}$ immediately before heating at $100^{\circ}$, protected the enzyme to some extent, whereas an equivalent concentration of the product of enzymic hydrolysis (penicilloic acid) had only a slight effect on the thermostability (Table 2 ). The penicilloic acid was prepared by incubating the penicillin and enzyme together at $30^{\circ}$ before treatment. The greater part of the enzyme prepared as described in 'Methods' was formed adaptively, following induction by addition of the substrate. This preparation was compared with that of 'basal' enzyme produced without added penicillin, but no difference in thermostability could be detected (Manson \& Pollock, to be published).

Miscellaneous. 8-Hydroxyquinoline at the concentration $\left(8 \cdot 3 \times 10^{-4} \mathrm{M}\right)$ used for inhibiting adaptation had no effect on thermostability, but another chelating agent ethylenediamine tetra-acetic acid ('Versene', Bersworth Chemical Co., Framingham, Mass.) in high concentrations $(0.005$ and $0.5 \mathrm{M})$ and gum acacia $1 \%(\mathrm{w} / \mathrm{v})$ each had slight protective properties.

\section{DISCUSSION}

The results show that the penicillinase in these preparations is rapidly inactivated in aqueous solution at $100^{\circ}$, but can be strikingly protected by the addition of gelatin or some high molecular weight compounds present in complex media. A similar observation with pectic enzymes has been made by 
Matus (1948), who found that gelatin and other compounds gave some protection against heat inactivation up to $60^{\circ}$. This effect was shown by penicillinase from four of the five strains tested and to a lesser extent by that from the fifth strain $(\mathbf{E})$. It thus appears that the heat stability of penicillinase in crude preparations depends on the other constituents present during heat treatment, rather than on the bacterial source. The decreased protective action of gelatin on the penicillinase from strain $\mathbf{E}$ and its inability to protect enzyme in commercial preparation $\mathrm{F}$, may be partly due to destruction of the gelatin by the gelatinase known to be present in both these cases.

It is possible that the protective effect of gelatin is due to its combination with the enzyme to form a heat stable complex. This is indeed suggested by the time curves for penicillinase inactivation shown in Tables 1 and 2, where it can be seen that little further enzyme was destroyed by prolonging heat treatment from 2 to $5 \mathrm{~min}$. The immediate loss in $2 \mathrm{~min}$. might thus be due to inactivation of the labile unassociated enzyme and the slow subsequent loss to that of the fraction stabilized by combination with gelatin or other protecting substance. The stabilizing action of a substrate on its enzyme is well known, and the protective effect of penicillin against destruction of penicillinase at $100^{\circ}$ is almost certainly due to the formation of a relatively stable enzyme-substrate complex.

We wish to thank the various manufacturers concerned for their co-operation in sending us samples of penicillinase, details of techniques and media employed in their preparation, and subcultures of bacterial strains used.

\section{REFERENCES}

Abraham, E. P. \& Chain, E. (1940). An enzyme from bacteria able to destroy penicillin. Nature, Lond. 146, 837.

DUthIE, E. S. (1944). The production of penicillinase by organisms of the subtilis group. Brit. J. exp. Path. 25, 96.

Florey, H. W., Chain, E., Heatley, N. G., Jennings, M. A., Sanders, A. G., Abraham, E. P. \& Florey, M. E. (1949). Antibiotics, vol. II, ch. 33, London: Oxford University Press.

Gladstone, G. P. \& Fuldes, P. (1940). A simple culture medium for general use without meat extract or peptone. Brit. J. exp. Path. 21, 161.

Hartley, P. (1922). The value of Douglas's medium for the production of diphtheria toxin. J. Path. Bact. 27, 479.

Henry, R. J. \& Housewright, R. D. (1947). Studies on penicillinase. II. Manometric method of assaying penicillinase and penicillin, kinetics of the penicillinpenicillinase reaction and the effects of inhibitors on penicillinase, J. biol. Chem. $167,559$.

Matus, J. (1948). Untersuchungen über die Aktivität der Pektinase. Ber. schweiz. bot. Ges. 58, 319.

Sмiтн, W. \& Sмiтh, M. M. (1945). Production of sterile and stable penicillinase. Lancet, i, 809.

Wright, H. D. (1933). The importance of adequate reduction of peptone in the preparation of media for the pneumococcus and other organisms. J. Path. Bact. 37, 257 .

(Received 30 July 1952) 